\title{
Serum uric acid concentrations in an urbanized South African Negro population
}

\author{
P. BEIGHTON, L. SOLOMON, C. L. SOSKOLNE,* B. SWEET, AND G. ROBIN† \\ From the Department of Orthopaedic Surgery, Medical School, University of Witwatersrand, \\ Johannesburg, South Africa
}

There is considerable geographical variation in population serum uric acid (SUA) concentrations. These discrepancies may be due to ethnic factors, or may be the consequence of environmental influences.

We have recently reported the results of a survey of SUA levels in South African Negroes living in a rural area (Beighton, Solomon, Soskolne, and Sweet, 1973). In order to assess the influence of the environment, we subsequently undertook a survey in an urban community of similar ethnic stock. The results of this investigation are presented in this paper.

\section{Urban population and its environment}

Soweto is an African city of over 500,000 inhabitants situated to the South of Johannesburg, on the Witwatersrand, in South Africa. The area is at an altitude of 6,000 feet, and the climate is generally hot and dry. Initially, workers migrated to Soweto from rural areas, attracted by employment prospects. However, many of the present inhabitants were born in the city. Various groups are represented, such as the Tswana, Zulu, and Xhosa. Ethnically they are all closely related to each other, being derived from the Negroes of Central Africa.

\section{Methods}

\section{(a) Survey}

The group investigated was chosen at random after a census. Each respondent was examined clinically, radiographs of the hands and feet were obtained, and blood specimens were taken from all adults. Completion rates of over $75 \%$ were achieved for each aspect of the investigation. Individuals of non-Negro stock and of mixed parentage were excluded from the survey. A significant proportion of the remaining respondents were members of the same tribal group, the Tswana, whom we previously investigated in a rural environment.

Full details of demography and methodology of this Soweto urban survey have been published elsewhere (Solomon and Robin, 1974).

\section{(b) Laboratory}

The sera were separated shortly after collection and stored at $-15^{\circ} \mathrm{C}$ for 6 weeks. SUA levels were determined by auto-analysis using automated modification of the Folin method (Buchanan, Isdale, and Rose, 1965). The technique used was identical to that employed in our previous SUA survey in the rural Tswana population.

\section{(c) Statistical}

The ponderal index (PI), an expression of somatotype, was calculated for each individual. According to Acheson and Chan (1969), a PI of 10.5 indicates considerable obesity, while 14.0 would be applicable to a very thin person. Data were analysed by computer and, where appropriate, the results were expressed in the form of fitted curves.

\section{Results}

Serum specimens were obtained from 144 males and 280 females, aged 15 and over, who were also examined clinically and radiologically. No respondent had clinical or radiological evidence of gout.

The relationship between age and SUA concentration is shown for males and females in Fig. 1. For

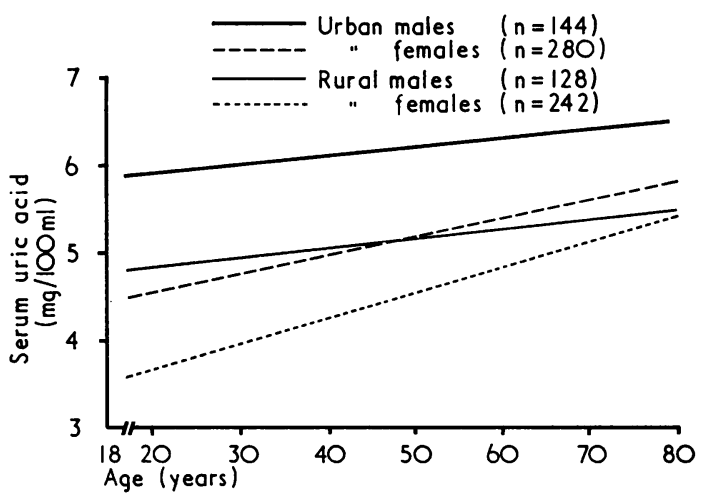

FIG. 1 Average SUA levels in relation to age and sex, shown by a fitted curve, for the urban and rural populations

Accepted for publication February 28, 1974.

Reprint requests to Professor P. Beighton, Department of Human Genetics, Medical School, University of Cape Town, Cape Town, South Reprint

* Department of Epidemiology and Biostatistics, National Research Institute for Occupational Diseases of the South African Medical Research

Council, Johannesburg.

† Present appointment: Assistant Professor of Orthopaedic Surgery, Hadassah Hospital, Jerusalem, Israel. 
comparison, the results previously published for the rural Tswana community are also displayed. Although the general trends are similar at any age and for either sex, the SUA concentrations in the urban group are consistently higher than those of the rural community. This discrepancy is statistically significant at the 0.01 level.

The mean, standard deviation, and range of SUA values are given in Table I. Average SUA values for males and females aged 20 and over in the urban and rural groups are compared in Table II. For both sexes mean SUA concentrations are significantly higher in the urban than in the rural groups $(\mathrm{P}<$ 0.001).

The relationship between SUA and the somatotype in terms of PI for respondents aged 20 and over in both populations is shown in Table III. The negative correlation coefficients indicate that the obese

Table I SUA levels (mean, standard deviation, and range) by sex and age for the urban population

\begin{tabular}{|c|c|c|c|c|c|}
\hline \multirow[t]{2}{*}{ Age group (yrs) } & \multirow[t]{2}{*}{ No. of patients } & \multirow{2}{*}{$\begin{array}{l}\text { Mean SUA } \\
(\mathrm{mg} / 100 \mathrm{ml})\end{array}$} & \multirow[t]{2}{*}{$S D$} & \multicolumn{2}{|c|}{ Range $(\mathrm{mg} / 100 \mathrm{ml})$} \\
\hline & & & & Low & High \\
\hline $\begin{array}{l}\text { Males } \\
15-19\end{array}$ & 11 & $5 \cdot 7$ & 1.09 & $3 \cdot 7$ & $7 \cdot 2$ \\
\hline $20-24$ & 21 & $6 \cdot 6$ & $1 \cdot 27$ & $3 \cdot 5$ & $9 \cdot 7$ \\
\hline $25-34$ & 30 & 5.9 & $1 \cdot 25$ & $3 \cdot 8$ & $8 \cdot 1$ \\
\hline $35-44$ & 23 & $5 \cdot 7$ & $1 \cdot 84$ & 1.0 & 8.7 \\
\hline $45-54$ & 15 & $\overline{6 \cdot 4}$ & 1.69 & $4 \cdot 2$ & 9.9 \\
\hline $55-64$ & 20 & $6 \cdot 4$ & $1 \cdot 19$ & 4.9 & $9 \cdot 6$ \\
\hline $65-74$ & 17 & $5 \cdot 4$ & $1 \cdot 22$ & $2 \cdot 3$ & $8 \cdot 2$ \\
\hline$\geqslant 75$ & 7 & 6.9 & 0.71 & 6.0 & $8 \cdot 1$ \\
\hline Total & 144 & $6 \cdot 1$ & 1.44 & 1.0 & 9.9 \\
\hline $\begin{array}{r}\text { Females } \\
15-19\end{array}$ & 23 & $4 \cdot 5$ & 0.95 & $2 \cdot 8$ & $6 \cdot 3$ \\
\hline $20-24$ & 44 & $4 \cdot 7$ & 1.06 & $2 \cdot 8$ & $7 \cdot 4$ \\
\hline $25-34$ & 59 & 4.9 & $1 \cdot 36$ & $2 \cdot 6$ & $8 \cdot 8$ \\
\hline $35-44$ & 36 & $5 \cdot 2$ & 1.05 & $2 \cdot 7$ & $7 \cdot 2$ \\
\hline $45-54$ & 31 & $5 \cdot 3$ & 1.43 & $2 \cdot 7$ & 8.8 \\
\hline $55-64$ & 39 & $5 \cdot 7$ & $1 \cdot 39$ & $3 \cdot 3$ & $9 \cdot 6$ \\
\hline $65-74$ & 36 & $5 \cdot 7$ & 1.41 & $2 \cdot 7$ & $9 \cdot 2$ \\
\hline$\geqslant 75$ & 12 & $5 \cdot 6$ & 1.26 & $\overline{3.7}$ & $7 \cdot 8$ \\
\hline Total & 280 & $5 \cdot 2$ & $1 \cdot 34$ & $2 \cdot 6$ & $9 \cdot 6$ \\
\hline
\end{tabular}

Table II Comparative data; mean, standard deviation, and range of urban and rural SUA concentrations in males and females

Males

Age group (yrs)

Soweto (urban) $15-90$

Tswana (rural) 14-84

No. $\quad S U A \quad S D$

\begin{tabular}{|c|c|}
\hline \multicolumn{2}{|c|}{ Range } \\
\hline Low & High \\
\hline $\begin{array}{l}1.0 \\
2.9\end{array}$ & $\begin{array}{r}9 \cdot 9 \\
10 \cdot 6\end{array}$ \\
\hline
\end{tabular}

Females

\begin{tabular}{|c|c|c|c|c|c|}
\hline \multirow{2}{*}{$\begin{array}{l}\text { Age } \\
\text { group } \\
(y r s)\end{array}$} & \multirow[t]{2}{*}{ No. } & \multirow[t]{2}{*}{$S U A$} & \multirow[t]{2}{*}{$S D$} & \multicolumn{2}{|c|}{ Range } \\
\hline & & & & Low & High \\
\hline $\begin{array}{l}15-90 \\
14-96\end{array}$ & $\begin{array}{l}280 \\
242\end{array}$ & $\begin{array}{l}5 \cdot 2 \\
4 \cdot 5\end{array}$ & $\begin{array}{l}1 \cdot 34 \\
1 \cdot 18\end{array}$ & $\begin{array}{l}2 \cdot 6 \\
1 \cdot 1\end{array}$ & $\begin{array}{r}9 \cdot 6 \\
11 \cdot 1\end{array}$ \\
\hline
\end{tabular}


Table III PI and SUA concentrations in the urban and rural populations

\begin{tabular}{|c|c|c|c|c|c|c|c|}
\hline \multirow[t]{2}{*}{ Population } & \multicolumn{3}{|l|}{$P I$} & \multirow{2}{*}{$\begin{array}{l}\text { Correlation } \\
\text { coefficient }\end{array}$} & \multicolumn{3}{|l|}{$S U A$} \\
\hline & Mean & $S D$ & No. & & Mean & $S D$ & No. \\
\hline $\begin{array}{l}\text { Male } \\
\text { Urban }\end{array}$ & $12 \cdot 63$ & 0.63 & 151 & $\begin{array}{l}-0.140 \\
(\text { no. }=133)\end{array}$ & $6 \cdot 1$ & $1 \cdot 47$ & 133 \\
\hline Rural & 12.99 & 0.64 & 140 & $\begin{array}{l}-0.356 \\
(\text { no. }=86)\end{array}$ & $5 \cdot 0$ & $1 \cdot 12$ & 102 \\
\hline $\begin{array}{c}\text { Female } \\
\text { Urban }\end{array}$ & $11 \cdot 56$ & 0.87 & 292 & $\begin{array}{l}-0.313 \\
\text { (no. }=257)\end{array}$ & $5 \cdot 2$ & $1 \cdot 35$ & 257 \\
\hline Rural & 12.06 & 0.92 & 278 & $\begin{array}{l}-0.338 \\
\text { (no. }=182)\end{array}$ & $4 \cdot 7$ & $1 \cdot 42$ & 218 \\
\hline
\end{tabular}

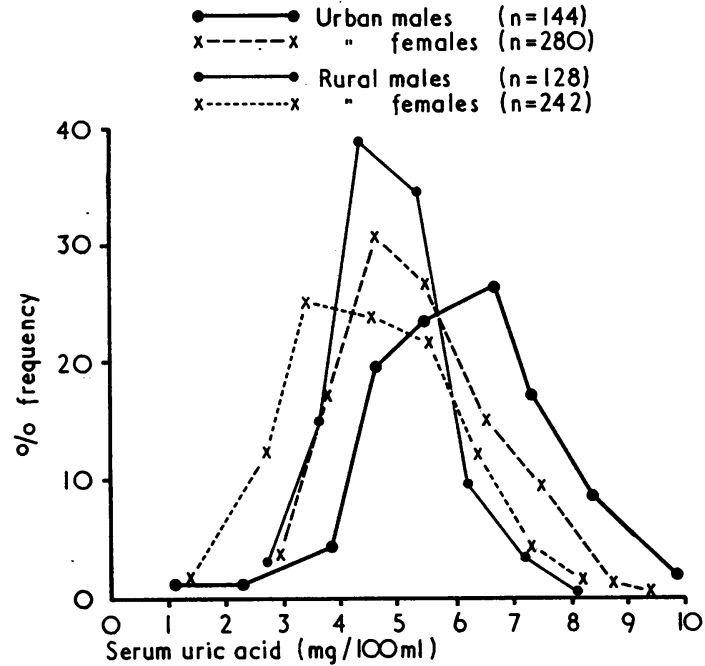

FIG. 2 Frequency distribution of SUA levels in males and females for the urban and rural populations

individuals tend to have higher SUA levels. However, the relationship is only marginally significant in the urban males. Considering the sexes separately, the respective differences between the average PIs and SUA concentrations in the two populations are statistically significant at the $1 \%$ level.

Percentage frequency distribution of SUA concentrations for males and females in the urban and rural populations are shown in Fig. 2. In each instance the curves are unimodal, suggesting normal distribution of SUA levels in these populations. In both groups the shift to the left of the curves for the females with respect to those for the males is consistent with their respective mean values. The populations differ in that data for urban males are clearly more spread about their mean than are those for rural males.

\section{Discussion}

The age-sex relationships of the SUA levels in the two African Negro populations are very similar, but the average SUA concentrations at any particular age in the urban group are significantly higher than those of the rural community. From an ethnic and genetic point of view, the two populations are virtually identical and this difference must therefore be the result of environmental factors.

It is impossible to pinpoint any particular environmental determinant. Among those which could be responsible, either singly or in combination, are the following.

\section{(a) Altitude}

Altitude has been shown to influence SUA levels (Acheson, 1970). The rural group lives at 1,100 metres above sea level, while Soweto is situated at an altitude of approximately 1,800 metres. However, this difference of 700 metres is unlikely to account for the discrepancy in SUA levels.

\section{(b) Infection}

Tuberculosis is endemic in both communities. Standards of health are otherwise reasonably good and there are no obvious differences in pattern of infection.

\section{(c) Stress}

The rural group lives a quiet tranquil life, while the urbanized population contends with all the problems inherent in big city life. Stress, in the nonspecific sense, may well represent a real difference between these groups.

(d) Diet

There are no obvious dietary differences between the communities. Both have a 'Westernized' diet and nutrition is generally adequate. Iron overload, due to 
dietary habits, produces significant morbidity in both communities, but this factor is unlikely to be associated with serum uric acid concentrations.

\section{(e) Body weight}

The inverse relationship between SUA and PI is similar to that observed in other populations (O'Brien, Burch, and Bunim, 1966; Acheson and Chan, 1969). Similarly, the unimodality of the frequency distribution curves is in accordance with the results of other epidemiological investigations ( $O$ 'Brien and others, 1966).

Nicholls and Scott (1972) have shown that loss of weight in obese individuals is accompanied by a fall in SUA levels, and they suggested that the influence of body weight on SUA concentrations might be responsible for the association between these two variables which have been observed in epidemiological and clinical studies.

The difference in SUA concentrations in the two African groups may be related in this way to the discrepancies in the average PIs of adults in these communities. A comprehensive statistical analysis of this situation has now been instituted.

The rise in average SUA concentrations, which appears to be the consequence of urbanization, has its parallel in other parts of the world. For instance, the Chinese of Taiwan have lower SUA levels than their relatives who have emigrated to Malaya and Western Canada (Ford and de Mos, 1964).

It is the general experience in medical centres in Southern Africa that while gout, the clinical consequence of hyperuricaemia, is uncommon in urbanized African Negroes, it is rare or absent in rural Negro populations. However, apart from gout, SUA levels are associated with conditions such as hypertension and myocardial infarction. These conditions are also unusual in rural African Negro populations but they are being encountered with increasing frequency in the urban groups, and they presumably represent yet another effect of change of environment and life style. The enhanced SUA concentrations which we have shown in the urbanized African Negro may well be of importance in this situation.

\section{Summary}

During the course of an epidemiological investigation, SUA concentrations were measured in 424 members of an urbanized South African Negro population.

The relationships between SUA, age, and sex were comparable to those shown in other populations. However, the average SUA concentrations in the urbanized group were significantly higher than those of an ethnically similar rural community $(P<0.001)$. This discrepancy in SUA levels, which is apparently determined by environmental factors, may be related to the increase in clinically important disorders such as hypertension and myocardial infarction, which has occurred in recent years in the urbanized African Negro.

We are grateful to the people of Soweto for their willing participation in the investigation; to the Department of Bantu Administration for their permission for the survey to be undertaken; to Mrs Greta Beighton for preparing the tables and typing the manuscript; and to the President of the Human Sciences Research Council, Pretoria, for the provision of computer facilities.

P.B. was in receipt of a Geigy Fellowship awarded by the Arthritis and Rheumatism Council of Great Britain.

The survey was supported by a grant from the University of the Witwatersrand Orthopaedic Chair Foundation Fund.

\section{References}

ACHeson, R. M. (1970) Proc. roy. Soc. Med., 63, 193 (Epidemiology of serum uric acid and gout: an example of the complexities of multifactorial causation)

—, AND Chan, Y. K. (1969) J. chron. Dis., 21, 543 (New Haven survey of joint diseases. Prediction of serum uric acid in a general population)

Beighton, P., Solomon, L., Soskolne, C. L., And Sweet, B. (1973) Ann rheum. Dis., 32, 346 (Serum uric acid concentrations in a rural Tswana community in Southern Africa)

Buchanan, M. J., IsDale, I. C., AND Rose, B. S. (1965) Ibid., 24, 285 (Serum uric acid estimation)

FORD, D. K., AND DE MOS, A. M. (1964) Canad. med. Ass. J., 90, 1295 (Serum uric acid levels of healthy Caucasian, Chinese, and Haida Indian males in British Columbia)

Nicholls, A., AND SCOTT, J. T. (1972) Lancet, 2, 1223 (Effect of weight-loss on plasma and urinary levels of uric acid)

O'Brien, W. M., Burch, T. A., AND Bunim, J. J. (1966) Ann. rheum. Dis., 25, 117 (Genetics of hyperuricaemia in Blackfeet and Pima Indians)

Solomon, L., AND RoBiN, G. (1974) (in press) (Rheumatoid arthritis in an urban South African Negro population) 